І. М. Клименко

канд. філол. наук, доцент

\title{
МІЖМОВНІ ЛЕКСИКО-СЕМАНТИЧНІ ВІДНОШЕННЯ (НА МАТЕРІАЛІ АНГЛІЙСЬКОÏ ТА УКРАЇНСЬКОЇ ФРАЗЕОЛОГІЇ)
}

У статті досліджено проблему визначення типів міжмовних відношень на лексико-семантичному рівні. Розглянуто випадки еквівалентності, включення, пересічення та безеквівалентності на прикладі англійської та украӥнської фразеологічних систем.

У сучасній лінгвістиці проблема визначення основних типів міжмовних відношень зостається поки що відкритою. Причини такої ситуації пояснюються великим різноманіттям семантичних кореляцій, що існують як між лексичними одиницями різного рівня, так і між різними мовами. Кожний приклад лексичних зіставлень має свої неповторні риси, які лише досить умовно можна об'єднати в деяку узагальнену модель $[8,122]$. Головним при цьому $є$ питання класифікації, тобто визначення тих вихідних ознак, за якими можна встановити типологію міжмовних лексичних відношень. Так, В. Г. Гак $[6,107]$ зазначав, що в мовах світу можливо вивести лише декілька десятків або сотень універсальних відповідностей на базі порівняльно-типологічного матеріалу. Він запропонував типологію лексико-семантичних відношень, в основі якої лежить структура словесного знака і його асиметрія на міжмовному рівні, що проявляється в семіотичному, парадигматичному та синтагматичному планах. Залежно від характеру асиметрії в кожному аспекті виділяється певна кількість типів відношень. Наприклад, у межах парадигматичної асиметрії спостерігається розходження за структурою номінації, коли одна внутрішня форма втілюється в кількох зовнішніх. Тому семантична близькість лексичних одиниць (як слів, так і фразеологізмів), що зіставляються, визначається ступенем їх еквівалентності, або ступенем збігу семантичних ознак у структурах лексичних значень. 
Виходячи 3 цих теоретичних положень, В. Н. Манакін пропонує досить просту та певною мірою універсальну класифікацію можливих типів таких відношень $[8,128]$. Цей підхід узгоджується із законами підпорядкування понять у формальній логіці. У результаті всю багатогранність відношень лексичних одиниць, що зіставляються в мовах, можна звести до трьох основних типів: повний збіг (еквівалентність), частковий збіг (з двома різновидами - включенням та пересіченням семантики), незбіг (виключення).

Розглянемо кожен 3 цих типів детальніше стосовно фразеологічних одиниць англійської та української мов.

Лексико-семантичні відношення збігу: еквівалентність. Лексичний рівень мови має своєю одиницею дослідження не тільки слово, але і стійке сполучення слів, або фразеологічну одиницю. Більшість теорій, що описували типи міжмовних лексико-семантичних відношень, торкалися лише слів $[1 ; 2 ; 3 ; 7 ; 10]$. Тому ми вважаємо доцільним прослідити, як спрацьовують існуючі теорії на фразеологічному підрівні.

3 поняттям еквівалентності зіштовхується кожен лінгвіст, що вивчає різні типи порівнянь - мовні та позамовні. Категорію еквівалентності в певному сенсі можна вважати центральною і універсальною при дослідженні різного роду взаємовідношень мовних одиниць у системі, оскільки основна мета аналізу мов - це встановлення складу і функцій за інтегральними (еквівалентними) і диференціальними ознаками $[8,124]$.

Еквівалентність розуміється як рівноцінність, рівнозначність. Виходячи 3 цього, еквівалентними необхідно вважати такі одиниці А і В що повністю співпадають за усіма ознаками в рамках однієї або різних систем, що зіставляються, тобто одиниці, між якими встановлюються відношення тотожності: $\mathbf{A}=\mathbf{B}$. Часто такий тип відношення лексичних одиниць визнається базовим, відправним, відносно якого розглядаються інші лексикосемантичні відношення. Так, вважається, наприклад, що еквівалентними $є$ фразеологічні одиниці типу:

Achilles' heel «Ахіллесова п'ята»;

to wash one's hands «умити руки»;

in the twinkling of an eye «не встигнути кліпнути оком»;

a millstone about smb. 's neck «камінь на шиї»;

not to let one's left hand know what one's right hand does «ліва рука не відає, що робить права»;

from the bottom of one's heart «від усього серця»;

to cherish a viper i one's bosom «пригріти змію на грудях»;

for smb's fair eyes «заради чиїхось прекрасних очей».

У вищенаведених одиниць еквівалентність проявляється в збігу як смислу, так і структури й образного ряду. На фразеологічному рівні при зіставленні англійської та української мов не доводиться говорити про значну кількість еквівалентих одиниць. Вони поширені серед фразеологічних 
одиниць, що походять із давніх джерел - із біблейських текстів, із міфології тощо.

Якщо виходити 3 необхідності суміщення ономасіологічного та семасіологічного аспектів при аналізі лексико-семантичних відповідностей у зіставлюваних мовах, то кількість взаємоеквівалентних одиниць-слів невелика навіть у споріднених мовах. Але таке суміщення є важливим переважно на загальнотеоретичному рівні для доведення різниці уявлень у конкретних національно-мовних культурах єдиного когнітивно-семантичного простору. Категорію еквівалентності в порівняльній лексикології слід застосовувати тільки до таких лексико-семантичних відповідностей, які мають максимальний збіг у складі і змісті семантичних ознак, що входять у структуру їх лексичних значень. Про встановлення еквівалентності на рівні змістової структури говорити складно, оскільки, по-перше, словникові дефініції структурують найбільш імовірні моделі лексичних значень, а не змістів лексичних одиниць, по-друге, лексичне значення $\epsilon$ найбільш стійкою сутністю, що найбільш наближене до концептів мислення та реальності $[5,115]$. Змістова структура лексичної одиниці, зокрема її імплікаційна частина, для кожного, хто займається контрастивним аналізом лексики різних мов, служить визначником реальної семантичної близькості або віддаленості тієї чи іншої зіставлюваної пари. Необхідність безпосереднього використання змістової структури лексичної одиниці при зіставленні лексико-семантичних відповідностей виникає лише тоді, коли словниковий варіант структури значення викликає сумніви, потребує уточнення.

Відношення часткового збігу: включення. Відношення включення означає, що в значенні лексичної одиниці має більше сем, ніж у значенні відповідної одиниці іншої мови, тобто в семний склад значення лексичної одиниці мови А входить усе значення одиниці мови $\mathbf{B}$ плюс ще якісь семи чи навпаки. Стосовно фразеології відношення включення можна сформулювати як наявність у лексико-семантичній структурі фразеологічної одиниці більшої (меншої) кількості варіантів значень, ніж у структурі фразеологізму іншої мови [7, 339-340].

На рівні слова міжмовні лексико-семантичні відношення проявляються ширше, ніж у фразеології. Вони, наприклад, відбиваються у гіпо- та гіперонімічних відмінностях. Гіперонімія - це недиференційованість значень одної мови у відношенні до іншої, де ці значення диференціюються (гіпонімія). Такі відношення зустрічаються в різних мовах і торкаються широких тематичних пластів лексики. Так, англійському слову coat в українській мові відповідають різні види верхнього одягу: пальто, плащ, мундир, китель. Гіпо-гіперонімічні зв'язки на фразеологічному підрівні не спостерігаються, але представлені інші аспекти відношення включення, що охоплюють семантичну структуру фразеологізму. В англійській та українській мовах є одиниці з різною кількістю лексико-семантичних варіантів значення. Наприклад, порівняйте: 
to be born with a silver spoon in one's mouth - 1 . «to be born under a lucky star, to be lucky»; 2. «to be born into a wealthy family» - та народитися y сорочиі - «бути щасливим, таланистим»;

on smb's hands - «resting on one as a responsibility» - та на руках 1. «під опікою»; 2. «у розпорядженні, у володінні»;

behind smb's back - «without his knowledge (always in connection with smth unpleasant, such as slender)»- та поза очi - 1. «у відсутність, щоб ніхто не чув і не бачив»; 2. «не бачачи особисто».

Відношення включення, на думку семасіологів, є важливим показником у зіставній семасіології. Вони є показником того, що в одній мові той чи інший предмет не має спеціального найменування, тобто певне поняття, що існує в мисленні носіїв мови у вигляді комплексу семантичних ознак, не закріплене окремим словесним знаком, для висловлення цього поняття використовується найменування більшого класу предметів, у той час як в іншій мові відповідне явище виділяється окремою семою. Ця ознака більшою мірою характерна для неспоріднених мов.

Відношення включення дозволяють виявити особливості порівнюваних лексичних одиниць, в семантико-стилістичному та конотативнопрагматичному аспектах. Тут можна спостерігати значні для національних культур особливості диференціації концептів. Слід відзначити, що урахування відношень включення між значеннями зіставлюваних одиниць є суттєвим у художньому перекладі.

Відношення часткового збігу: пересічення. Відношення пересічення $(\mathbf{A} \cap \mathbf{B})$ спостерігаються у тих випадках, коли значення начебто накладаються одне на інше, але в кожного з них зостається і не накладена, окрема, частина. Для відношення пересічення застосовується також термін гетеронімія. Цей тип відношень об'єднує такі пари лексико-семантичних відповідностей зіставлюваних мов, які означають дещо різні, але дуже схожі за своєю природою і функціям денотати і уявлення про них. Наприклад:

to be on one's feet - 1. «be standing»; 2. «rise (to speak)»; 3. «be in good health after an illness» - та бути на ногах - 1. «не спати»; 2. «клопотати, перебувати у турботах»; 3. «бути здоровим після хвороби»; 4. «стояти».

У наведених прикладах значення, що не пересікаються, - це «rise (to speak)» in «to be on one's feet» та «не cnати» в «бути на ногах». Крім того, значення «стояти» має різну частотність в англійській та українській мовах. В українській воно вживається рідко. Останні лексико-семантичні варіанти утворюють компонент пересічення.

Наведемо інші приклади фразеологізмів із відношеннями пересічення в англійській та українській мовах:

to throw dust in one's eyes - «to mislead someone, to prevent from seeing the truth»- та замилювати очi - «за допомогою ефектних вчинків представляти свій стан кращим, ніж він є»; 
Jack of all trades - «person who can turn his hand to anything, workman knowing something of many trades (a master of none)»- та майстер на всі ру$\kappa и$ - «людина, здатна до будь-якої справи, що вміє все робити майстерно».

В останньому прикладі компонент, що не співпадає, - це конотація. В англійській мові вона негативна, в українській - позитивна.

Лексико-семантичні відношення пересічення спостерігаються також у фразеологічних одиницях з однаковим значенням та з різним образним компонентом, з різною метафоричною базою, що визначається особливостями національного сприйняття дійсності. До таких фразеологізмів належать:

a bird in hand is worth two in the bush - краще синиця в руиі, ніж журавель у небі;

to sleep with one eуe open - одним вухом спить, іншим чує;

to smite smb under the fifth rib - уразити в саме серие.

Окрему групу становлять фразеологізми, у яких в англійській та українській мовах збігаються змістові компоненти, але в одній 3 мов відсутній образний метафоричний компонент. Наприклад:

lily liver - боягузство;

of the right kidney - відповідний, цілкком порядний;

to stick to smb's rib - бути ситним, поживним;

to get one's brains fried - отримати сонячний удар;

to pass one's lips - проковтнути, з 'їсти, випити;

to put a bold face on smth - діяти сміло, не розгубитися;

dry behind the ears - дорослий, зрілий.

Лексико-семантичними відношеннями часткового збігу в англійській та українській мовах пов'язані фразеологізми з різним значенням, але спільною структурою та ії компонентами. Такі одиниці часто називають хибними друзями перекладача. До них відносяться:

англ. to lead by the nose - «мати за попихача»;

укр. водити за носа - «дурити»;

англ. to stretch one's legs - «розім'яти ноги, прогулятися»;

укр. протягнути ноги - «вмерти»;

англ. to twist smb round one's finger - «заставити діяти за чиїмось бажанням, позбавивши власної волі»;

укр. обвести навколо пальия - «обдурити».

Слід відзначити, що пересічення фразеологічних значень $є$ досить поширеним явищем при міжмовних порівняннях, і з точки зору контрастивного аналізу становить цікавий матеріал. Відношення часткового збігу спостерігаються на конотативно-прагматичного рівні, причому не завжди зіставляється семантичний компонент. Відмінності можуть стосуватися стилістичних особливостей, сфери мовних концептуальних понять, так званої етнічної ментальності взагалі.

Окремі лексико-семантичні відповідності еквівалентними є тільки умовно і в якомусь одному лінгвістичному вимірі $[8,138]$. Ступінь еквіва- 
лентності двох зіставлюваних лексичних одиниць, що в принципі співпадають у значеннях, визначається ступенем їх змістових відмінностей: найбільш еквівалентними $є$ такі значення порівнюваних одиниць, які мають мінімальні відмінності в своїх змістових структурах. Крайніми межами, що визначають семантичну відстань між лексичними одиницями, є відношення повного збігу (еквівалентності) і повного незбігу (безеквівалентності). Останній тип відношень стане об'єктом розгляду нижче.

Відношення незбігу: безеквівалентність. До цього типу належать фразеологізми, семантика яких співвідноситься 3 позначенням специфічних для певної культури реалій. Реалії є унікальними, єдиними у своєму роді одиницями, які певною мірою нема з чим порівнювати. Про безеквівалентну лексику немало написано дослідниками в царині лінгвокраїнознавства та перекладу [4; 9]. Для них також використовують терміни «етнографізми», «фонові слова», «одиниці з культурним компонентом» тощо. Ці поняття можна вважати співвідносними, оскільки одиниці, що ними називаються, ріднить національний, історичний колорит і відсутність еквівалентів в іншій мові, тобто без еквівалентність. у Безеквівалентними $є$ одиниці, змістовний план яких неможливо зіставити 3 якимось іншомовним лексичним поняттям. Дослідження подібних одиниць може відкрити багаті аспекти національних культур, виявити невивчені етнічні факти.

Можна виділити різні рубрики найменувань (тематичні групи), що позначають предмети матеріальної і духовної культури національних соціумів. Наведемо приклади деяких з них, у яких представлені фразеологізми 3 соматичним компонентом:

blue nose - «синій ніс», прізвисько жителів Канади та північносхідних штатів США, особливо штату Мен;

rabbit's foot - кроляча лапка, що має магічну силу;

buck eye - кінський каштан, що використовується як талісман.

Два останні приклади фразеологічних одиниць пов'язані з марновірством, забобонами, що є частиною культури англомовних країн.

Безеквівалентні сталі сполучення також представлені прізвиськами підлітків, які останні беруть із коміксів, мультфільмів; добір прізвиськ умотивований $[4,68]$. Наприклад:

Jug head («голова глечиком»);

Big mouth («великий рот», «базіка»);

Bird brain («курячий мозок»);

Numb skull («пустий череп»);

Horse face («коняча пика»);

Skin head («лисий череп»).

В українській мові явище надання прозвисьок із використанням соматичних компонентів серед підлітків теж досить поширене.

Постає питання про способи передачі безеквівалентних в іншій мові. Найбільш поширені $з$ них - це калькування (blue nose - «синій ніс») та 
описовий переклад (ту ж саму фразеологічну одиницю можна передати як «прізвисько жителів Канади та північно-східних штатів США»). Іноді для більш повного тлумачення ці обидва способи комбінуються.

\section{Список використаної літератури}

1. Аракин В. Д. Сравнительная типология английского и русского языков.- Л.: Просвещение, 1979. - 259 с.

2. Арсеньева Е. Ф. Сопоставительный анализ фразеологических единиц. - Казань: Изд-во Каз. ГУ, 1989. - 123 с.

3. Верба Л. Г. Порівняльна лексикологія англійської та української мов. - Вінниця: Нова книга, 2003. - 160 с.

4. Влахов С. И., Флорин С. П. Непереводимое в переводе. - М.: Р. Валент, 2006. $-448 \mathrm{c}$.

5. Гак В. Г. Сопоставительная лексикология. - М.: Международные отношения, 1977. $-246 \mathrm{c}$.

6. Гак В. Г. Языковые преобразования. - М.: Наука, 1998. - 312 с.

7. Кочерган М. П. Основи зіставного мовознавства. - К.: Академія, 2006. -424 с.

8. Манакин В. Н. Сравнительная лексикология. - К.: Знання, 2004. - 326 с.

9. Швейцер А. Д. Перевод и лингвистика. - М.: Наука, 1973. -325 с.

10. Korunets I. V. Contrastive Typology of the English and Ukrainian Languages. K.: Lybid, 1995. -239 p.

\section{Summary}

The paper examines the problem of interlingual relations at the lexical level. It studies the cases of equivalence, inclusion, overlapping and non-equivalence in the systems of English and Ukrainian phraseology. 